\title{
HUMAN IMPACTS ON LANDSCAPES: LESSONS OF CITIES FROM THE PAST
}

\author{
IMPACTOS HUMANOS NAS PAISAGENS: LIÇÕES DE CIDADES DO PASSADO \\ IMPACTS HUMAINS SUR LES PAYSAGES: LEÇONS DES VILLES DU PASSÉ \\ ERIC FOUACHE 1 \\ STÉPHANE DESRUELLES ${ }^{2}$
}

\begin{abstract}
${ }^{1}$ Professor at Sorbonne University, Senior Member of the IUF, U. R. Mediations Sciences des lieux, sciences des liens. Email: eric.g.fouache@wanadoo.fr.

${ }^{2}$ Sorbonne University, U. R. Mediations Sciences des lieux, sciences des liens.
\end{abstract}

\begin{abstract}
The first cities emerged in the Middle East at the end of the 4th millennium BC. Studies in the field of archaeology, geomorphology, geoscience and history allow us to understand which types of hazards were affecting the cities, and how they had an impact on landscapes in the past, in the Middle East, but also in other parts of the world. There is much to be gained: these studies are fundamental to a better understanding of present-day hazards, to urban development, but also to remembering our heritage. Cities have always been susceptible to nature's risks and natural disasters but have also - through urban development and through the proximity of great numbers of human beings -, generated their own specific hazards.
\end{abstract}

Key Words: Geoarchaeology. City. Hazards. Archaeology. Environment. Urban Development. Heritage.

\section{RESUMO}

As primeiras cidades surgiram no Oriente Médio no final do $4^{\circ}$ milênio aC. Os estudos no campo da arqueologia, geomorfologia, geociências e história permitem-nos compreender quais os tipos de perigos que afetavam as cidades e como tinham impacto nas paisagens no passado, no Médio Oriente, mas também noutras partes do mundo . Há muito a ganhar: estes estudos são fundamentais para uma melhor compreensão dos perigos da atualidade, para o desenvolvimento urbano, mas também para relembrar o nosso patrimônio. As cidades sempre foram suscetíveis aos riscos da natureza e desastres naturais, mas também - por meio do desenvolvimento urbano e da proximidade de grande número de seres humanos - geraram seus próprios perigos específicos.

Palavras-chave: Geoarqueologia Cidade. Riscos. Arqueologia. Meio Ambiente. Desenvolvimento Urbano. Patrimônio.

\section{RESUMÉ}

Les premières villes ont émergé au Moyen-Orient à la fin du 4e millénaire avant notre ère. Des études dans le domaine de l'archéologie, de la géomorphologie, des géosciences et de l'histoire nous permettent de comprendre quels types de dangers affectaient les villes et comment ils ont eu un impact sur les paysages dans le passé, au Moyen-Orient, mais aussi dans d'autres parties du monde. Il y a beaucoup à gagner: ces études sont fondamentales pour une meilleure compréhension des aléas actuels, pour le développement urbain, mais aussi pour se souvenir de notre patrimoine. Les villes ont toujours été exposées aux risques de la nature et aux catastrophes naturelles, mais elles ont également généré - grâce au développement urbain et à la proximité d'un grand nombre d'êtres humains - leurs propres risques spécifiques.

Mots clés: Géoarchéologie.Ville. Dangers. Archéologie. Environnement. Développement urbain. Patrimoine.

\section{INTRODUÇÃO}

If we see the end of the neolithization process as being around the year $6000 \mathrm{BC}$, in the Middle East first of all, then cities begin to appear after a long maturation period at the end of the $4^{\text {th }}$ millennium BC (BUTTERLIN, 2010). They sprung up on the banks of large rivers in Mesopotamia, in the areas that are now Iraq, Iran and Syria; and in the valleys of the River Nile, the River Jordan, the River Indus, the River Ganges and the Yellow River. The date of their emergence in Africa, Meso-America and South America is still disputed, but is more recent ('T HART; BLOCKMANS, 2016). What distinguishes cities from villages or clusters of little farming towns is the concentration in a single area of economic, political, social and religious powers, which was reflected in a high relative concentration of non-farming populations and in 
a monumental administration often enclosed within a surrounding wall (BUTTERLIN, 2010; NICOLLE, 2013).

Figure 1 - Location of localities mentioned in the article.

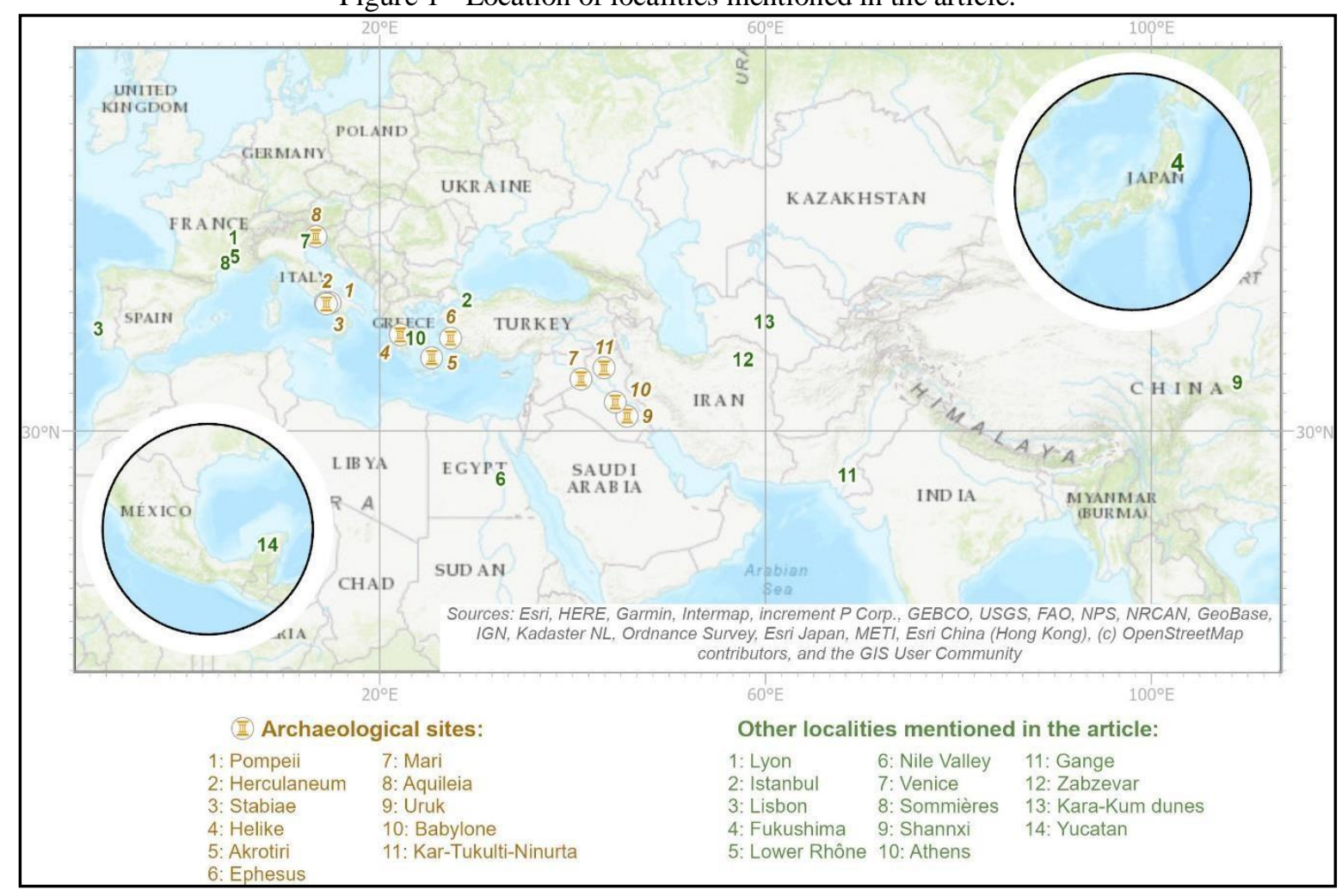

Source: Fouache; Desruelles (2020).

Geoarchaeology is an interdisciplinary approach that we define as being founded upon the use of methods and techniques drawn from geosciences, archaeology and geography, to recreate palaeoenvironments and landscape processes in a multi-scalar, diachronic archaeological perspective, in connection with human occupation (FOUACHE, 2010). The geo-archaeological approach allows us to comprehend the evolution of environmental processes over the course of time in an urban studies context, and the parallel evolution of the issues, the risks and thus the hazards of a city. Large modern-day developments, like the construction of an underground car-park in Lyon (Quai Saint Antoine), or the boring of tunnels in Istanbul (in the Yenikapi neighborhood; fig. 1), going under the Golden Horn and the Bosphorus to link old Stamboul to the Asian side of the city, have resulted in a proliferation of conservation-oriented archaeological excavations associated with environmental studies where ancient cities once stood; in this instance the identification of the bed of the River Saône in the early Iron Age (VOISIN, 2010), and the excavation of a $10^{\text {th }}-11^{\text {th }} \mathrm{C}$ AD Byzantine port (DEGREMONT, 2009). This is a major opportunity to bring together urban development, archaeology, and history; and to encourage understanding of environmental processes amongst urban populations by integrating the notion of heritage into this understanding (BINI et al., 2018). This is of importance to the whole world, and especially to the world's major cities.

Explaining the hazards of ancient cities can also serve as a great warning to the current generation and promotes prevention policies rooted in a real understanding of the interaction between natural processes and processes brought about by human societies. We must not, however, fall into any irrational fear of the risks of our environment. Between the Bronze Age 
in the Middle East, the Iron Age in Western Europe and the end of the modern era, examples of urban civilizations that have been destroyed solely by environmental disasters are rare.

\section{CITIES AND CATACLYSMS}

The greatest risk for cities of the past was, of course, as today, a cataclysm, be it the direct effects of a natural disaster or the effects of society. The most notable kinds of such cataclysms are volcanic eruptions, earthquakes, and tsunamis (FOUACHE, 2006; LIRITZIS et al., 2019; fig. 2). Numerous cities were erased from the map in this way: Pompeii, Herculaneum and Stabiae in Campania when Mount Vesuvius erupted in AD 79; Akrotiri in Santorini between 1635 and 1628 BC; and Helike swept into the Corinthian Gulf in 373 BC (fig. 1). The Lisbon earthquake of 1755 , followed by a tsunami and the destruction of the city by the ensuing fire, is a good example of how urban development can amplify the consequences of a catastrophe (fig. 1). The Fukushima catastrophe in 2011 is yet another in this long line (fig. 1). However, it is somewhat exceptional to see a city being completely erased from the map; in the past as in the present, cities normally rise from the ashes in the same place, providing that the political and social systems possess sufficient resources to do so, and that the city is produced by the socio-economic, political and religious systems. It is due to those socio-economic, political, and/or religious imperatives that the city is rebuilt in the same place, either because of the site or because of the image of the city. A city's exposure to 'natural' hazards is not, however, limited to cataclysms.

\section{NON-CATACLYSMIC NATURAL HAZARDS}

The frequent location of cities on the banks of rivers (BRAVARD; MAGNY, 2002) or by the sea puts them at the mercy of dramatic rises in water levels, floods and changing shorelines (MORHANGE et al., 2007). The original site of the city is often sheltered from these dangers, on a headland or hill; but as soon as the city has been established, a lower city, suburbs and a port, which are exposed, all come into existence; then, very soon after, urban growth spreads into at-risk areas, the original site being too small. An example of this is the town of Sommières in the Gard department (France; fig. 1), built at the foot of the hill on which the castle stands, right on the River Vidourle flood plain (BOULIER et al., 2018) despite the high frequency of floods originating in the Cevennes rains. The enforcement of collective riskmanagement measures can be a factor in the social acceptance of the hazard. Thus, the Ancient Egyptians viewed the floods of the Nile (fig. 1) as a nourishment of the land, and the Venetians very quickly learnt to live with the phenomenon of acqua alta (fig. 1). In the Roman city of Aquileia (fig. 1), the fluvial risk was considered to be secondary to the profits (economic, strategic, political) that societies made from the exploitation and the use of the Natisso River (ARNAUD-FASSETTA et al., 2010). Indeed, the site chosen can itself be the cause of a city's wealth. The ancient city of Mari (MARGUERON, 2004) on the Middle Euphrates in modernday Syria (fig. 1) was linked to the river, its irrigated farmland, and its waterway. Throughout the third and second centuries BC, these advantages enabled a costly development that the Sumerian civilization in Uruk (fig. 1) had the human and financial resources to support. The surrounding wall of Mari's earliest settlement ("Ville I", ca. 2900-2600 BC; BURKE, 2008) is considered by Margueron $(2000,2004)$ as a dyke for flood protection. 
Figure 2 - Plate boundaries and major cultural centres.

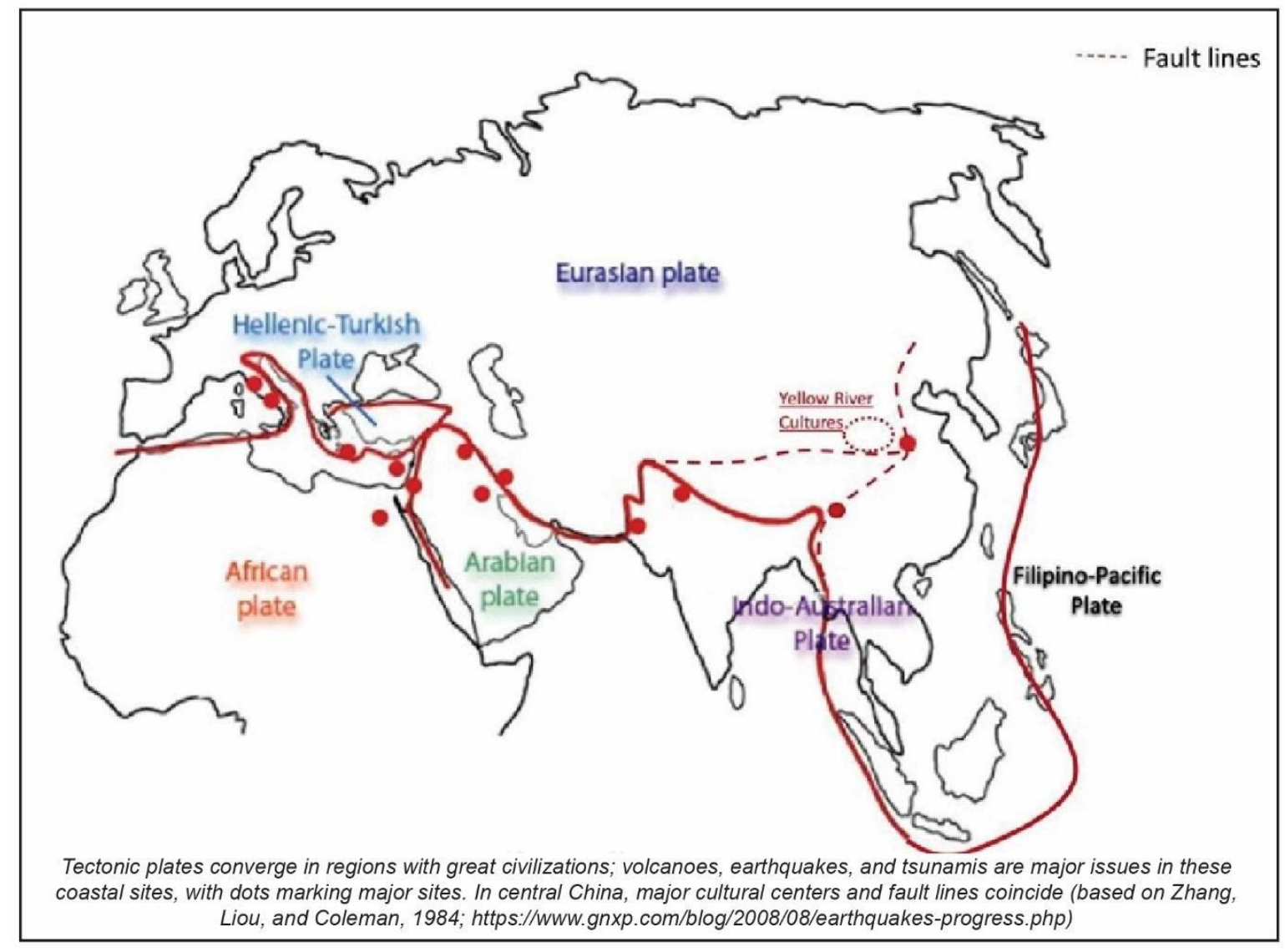

Source: Liritzis et al. (2019).

The same is true for Babylon on the Euphrates River (fig. 1), where many inscriptions found in relation to buildings mentioned flood defenses built during the reign of Nebuchadnezzar II (604-562BC) such as quay, canals, moats and dams (PEDERSÉN, 2014). In the end it was not the river's water levels that destroyed Babylon, but the Median invasion.

What geoarchaeological studies also teach us, as well as the studies of paleoclimatologists, is that at the level of the Holocene (MAYEWSKI et al., 2004) - the last 10,000 years -, environmental processes have varied: the seasonal distribution of weather types, temperatures (by a yearly average of roughly two degrees), rainfall (by irregular amounts) (BIRCK et al., 2005). The consequences of this variability are all the more emphasized in the marginal areas of the inhabited world, such as arid and sub-polar zones. As a result, the morphogenesis and the hydrological rhythms of rivers and thus the hydro-morphological hazards have evolved. For example, in its lower part, the hydrology of the Rhône River varied between calm periods such as the Medieval Warm Period, and other periods dominated by more exceptional occurrences, such as the Little Ice Age (ARNAUD-FASSETTA, 2000; 2008; 2009).

During the Holocene, the impact of non-cataclysmic natural hazards has greatly interplayed with anthropogenic forcing. The changes societies have brought to the exploitation of drainage basins have interacted with those natural processes, sometimes worsening environmental disasters, sometimes balancing them out (DIAMOND, 2006). This is how - due to erosion linked to the agricultural exploitation of its hinterlands and the progradation of the Küçük Menderes Delta - , the city of Ephesus (fig. 1) ended up ceasing to be a port (KRAFT 
et al., 2007). However, cities do not merely suffer from their environment, they affect it themselves.

\section{THE IMPACT OF CITIES ON THEIR ENVIRONMENT}

From the very beginning of its life, a city has a considerable impact on its environment. Huge numbers of inhabitants, as in Xi'an (fig. 1) where there were already about 100,000 inhabitants in $1000 \mathrm{BC}$ (MODELSKI, 2003), have always been conducive to epidemics (HAYS, 2005; LIANG et al., 2018), pollution (BORSOS et al., 2003), and a heightened consumption of energy and natural resources. The supposed plague that hit Athens (fig. 1) from 430 to 426 BC (HORNBLOWER et al., 2014), which was more probably a typhus epidemic, is still remembered today. Such paleopollution appears in geoarchaeology in the study of intrasite sediments (ZHANG et al., 2005), or that of sedimentary archives in ancient port basins (MORHANGE et al., 2015). Thus geoarchaeologists use levels of lead, scoria and heavy metals to trace and mark out the past, whilst the study of skeletons in necropolis offers a glimpse of the health of an ancient population and the impact of chronic illnesses and epidemics (WALDRON, 2009). The most finely developed ancient urban societies took measures against some of these risks, as far as the knowledge of their era allowed them to. One needs look no further than supplies of clean drinking water; fountains; urban water tanks; qanat networks (BRIANT, 2001) - which became commonplace across the Iranian plateau and beyond in the first millennium BC -, or Roman aqueducts (BONNIN, 1985); waste disposal and wastewater disposal; the establishment of cemeteries outside of the city; legislation aiming to curb the risk of fire; paraseismic construction practices; the building of dykes and levees; or the confinement of polluting activities or industries, for example tanneries situated in their own specific neighborhoods. We must be careful, however, not to apply modern standards of safety and responsibility to ancient urban societies.

\section{THE NEW RESPONSIBILITY OF CONTEMPORARY URBAN SOCIETIES}

In an epidemiological as well as an environmental sense, there is most definitely a difference in size between ancient and modern urban societies. Our civilization, with its knowledge of the tectonic plate theory and its vast progress in geosciences and biology, is the first to have gained a scientific understanding of the genesis of volcanic eruptions, earthquakes, tsunamis and landslides, as well as of the environmental disasters or health crises of the past, and the first to have conceived of forecasting such phenomena. Considering current scientific and technological expertise, preventing major and natural hazards should be a top priority for cities all over the world, based on a five-point plan: studying dangers, knowing what is at stake, defining risks, adopting urban planning regulations, and educating city-dwellers on the states of crisis specific to each urban context. Be it due to a lack of specialists, a lack of resources, an absence of political will, corruption, or misunderstood financial interests, such a plan is still a rare exception in the world today.

\section{WHAT CAUSES A CITY TO DISAPPEAR?}

Seeing as cities are each built on areas with their own topography, with site constraints and hazards linked to these dangers, they are social, economic, religious, and political products. By way of proof, all cities, throughout history, have been created either by a myth or by a decree. In the Middle East, the first cities to be recognized and partially explored were, obviously, new cities (MARGUERON, 2004), clearly built by political will. Later, foundations 
were in fact often found to be hiding refoundations, and the desire of authority to forever leave its mark on history. The city of Kar-Tukulti-Ninurta (EICKHOFF, 1985) is emblematic in this sense: situated on the right bank of the River Tigris (fig. 1), where modern-day Iraq stands, it was founded in such a way by King Tukulti Ninurta I, who ruled from 1244 to 1208 BC. This veritable new city boasted a design based on quadrilaterals, long orchard paths and baked-brick ramparts. The king wanted it to be a new capital, but he died before it was finished, and the city soon crumbled.

What archaeology teaches us is that cities disappear with the civilizations that founded them, for reasons often far more social, political, or religious than environmental (fig. 3). The aridification of the global climate (KUZUÇUOGLU; MARRO, 2007; FOUACHE et al., 2009) that followed the Holocene Climate Optimum is often put forward as the reason behind the great cultural crises that occurred in the Near East, such as the fall of the Akkad Empire (WEISS et al., 1993) in the Arabo-Persian Gulf, or the abandonment of Harappan cities in the Indus Valley (DUTT et al., 2019; fig. 1). This aridification was most probably caused either by thousand- or hundred-year fluctuations, by some sudden turn of events, or by a progressive evolution of the climate towards dryness, connected with the waning of the Indian monsoons (LÉZINE et al., 2007; DUTT et al., 2019). Pollen, speleothem and lacustrine deposit analyses in the region show that this waning of the Indian monsoons from 4700 to 4200 BP (IVORY; LÉZINE, 2009; DIXIT et al., 2014; DUTT et al., 2015), was very real, but an actual link with the collapse of late Bronze Age civilizations is debated (KNAPP; MANNING, 2016). The widespread collapse of Classic Maya polities occurred in a context of climate-driven environmental change between 600 and 1000 AD (KENNETT et al., 2012). A series of major droughts triggered a decline in agricultural productivity and contributed to societal fragmentation and political collapse (KENETT; BEACH, 2013).

When we discuss the collapse of Bronze Age civilizations in the Near and Middle East, we thus must take care to distinguish vast urban centers, economic, political and cultural hubs that are very dependent on external flows, and, as we have intimated, were very quickly abandoned at the end of the third millennium, and small urban and rural sites (ISSAR; ZOHAR, 2007) like those, for example, of the Sabzevar region (FOUACHE et al., 2010) in Iran (fig. 1), which have been occupied consistently throughout their existence. One must also consider the duration of aridification, which is by no means a quick and brutal process, but rather a slow evolution over the course of 600 years. To attribute the collapse of those Bronze Age civilizations to the only climactic factor in question seems, in the light of current archaeological knowledge, a gross simplification (KNAPP; MANNING, 2016).

If we move to Central Asia, and protohistoric Central Asia, recent archaeo-environmental research (CATTANI, 2005; FRANCFORT, 2005; FRANCFORT, 2009; FRANCFORT; TREMBLAY, 2010; LUNEAU, 2010; LIU et al., 2018) seems to be showing us that the pinnacle of Oxus civilization came at the end of this phase of aridification, proven by environmental studies (CREMASCHI, 1998; LUNEAU, 2019), notably the advance of the Kara-Kum dunes (fig. 1) and the parallel southerly advance of steppe peoples (CATTANI, 2005); its collapse, meanwhile, most likely came with the beginning of a new humid phase. 
Figure 3 - A systemic context for sociopolitical decline.

\begin{tabular}{|c|c|}
\hline POTENTIAL DELETERIOUS INPUTS & POSSIBLE MEDIUM-TERM CONSEQUENCES \\
\hline \multicolumn{2}{|l|}{ External } \\
\hline $\left.\begin{array}{l}\text { Warfare } \\
\text { Foreign Invasion } \\
\text { Disintegration of Alliances or } \\
\quad \text { Economic Networks } \\
\text { Pandemics } \\
\text { Environmental }\end{array}\right\}$ & $\begin{array}{l}\text { Deterioration/Destruction of Infrastructure/Agroeconomy } \\
\text { Declining Productivity } \\
\text { Shortages of Raw Materials } \\
\text { Rural Depopulation } \\
\text { Economic Recession, Deepened by Concatenations }\end{array}$ \\
\hline $\begin{array}{l}\text { *Recurrent Climatic Perturbations } \\
\downarrow \text { *Anthropogenic Degradation } \\
\text { Internal }\end{array}$ & $\begin{array}{l}\text { Declining Productivity and Food Stress- } \\
\text { Declining Productivity, Rural Poverty, and } \\
\text { Pressure for Short-Term Maximization }\end{array}$ \\
\hline $\begin{array}{l}\text { Exploitative Land-Owning Elites } \\
\text { Excessive Demands of Tax Collectors } \\
\text { Ethnic or Religious Intolerance of } \\
\text { Power Elites } \\
\text { Presence of Uncontrolled, Nonlocal } \\
\text { Pastoralists } \\
\text { Rural Insecurity } \\
\text { Contingencies }\end{array}$ & $\begin{array}{l}{\left[\begin{array}{l}\downarrow \\
\text { Rural Economic Decline } \\
\text { Rural Depopulation/Flight } \\
\text { Urban Decline } \longleftrightarrow \text { Increasing Social Stress }\end{array}\right.} \\
\begin{array}{l}\downarrow \\
\text { (compounded by state incompetence or dynastic instability) } \\
\downarrow\end{array}\end{array}$ \\
\hline Degree of Environmental/Social Resilience & Dynastic or Sociopolitical Devolution or Disjunction? \\
\hline $\begin{array}{l}\text { Sociopolitical decline can be caused by many i } \\
\text { degradation (marked by *). These variables are } \\
\text { range changes, which in this graphic represen } \\
\text { environmental history. The category of "continge } \\
\text { that help to defi ne different forms }\end{array}$ & $\begin{array}{l}\text { inputs other than climatic perturbations or anthropogenic } \\
\text { interlinked by multiple feedbacks, as are their medium- } \\
\text { ttation emphasize socioeconomic problems rather than } \\
\text { encies" spans a wide range of socioecological feedbacks } \\
\text { of resilience critical to long-term outcomes. }\end{array}$ \\
\hline
\end{tabular}

\section{FINAL CONSIDERATIONS}

We are fortunate to be able to use conservation-oriented archaeological digs to carry out, within a dense urban tissue, geo-archaeological studies of environmental processes. This affords us a better understanding of initial site constraints and allows us to piece together the dynamic evolution of environmental constraints which interacted with processes begotten by human development. This piecing together in turn affords us a better understanding of the perennial or random nature of hazards, lets us know when they will recur, and allows us to form more effective prevention policies. This environmental history can also form part of a city's heritage, a part that can be exhibited for all to see and- by placing a city's current situation in a dual history, that of the environment and that of human societies-, can be used for educational purposes in explaining the nature of hazards and the evolution of issues and risks. We must not, however, focus exclusively on environmental risks to our cities. Preventing major hazards, reducing pollutants and managing waste, optimizing the management of water resources, and harnessing the growth of megalopoles are all major issues; but- due to the huge numbers of inhabitants and their increasing concentration-, the greatest dangers to the long lives of our cities are actually, now as they always have been, social and political. 


\section{ACKNOWLEDGEMENTS}

I am most particularly indebted in the preparation of this article to Annie Caubet, the honorary General Curator of the Louvre Museum, for her remarks and suggestions on Middle Eastern cities and Joe Cunningham for translation.

\section{REFERENCES}

ARNAUD-FASSETTA, G. 4000 ans d'histoire hydrologique dans le delta du Rhône. De l'Âge du bronze au siècle du nucléaire. Grafigéo, 11, Mémoires et documents de l'UMR PRODIG, Paris, 2000, 229 p.

ARNAUD-FASSETTA, G. La Géoarchéologie Fluviale. Concepts, attendus et méthodes d'étude rétrospective appliquées à la caractérisation du risque hydrologique en domaine méditerranéen. Écho-Géo, 4, 2-11, 2008.

ARNAUD-FASSETTA, G. "Palaeohydrographic, palaeohydrological and palaeohydraulic investigations in Mediterranean geoarchaeology. Case studies of the Rhône River (France) and Isonzo River (Italy) deltas". In: De Dapper M., Vermeulen F., Deprez S., Taelman D. (eds) Ol' Man River. Geo-archeological Aspects of Rivers and River Plains. Archaeological Reports Ghent University 5, Academia Press, Ghent, 21-42, 2009.

ARNAUD-FASSETTA, G.; CARCAUD, N.; CASTANET, C.; SALVADOR, P.-G. Fluviatile palaeoenvironments in archaeological context: Geographical position, methodological approach and global change - Hydrological risk issues. Quaternary International, 216, 93$117,2010$.

BINI, M.; FABIANI, F.; PAPPALARDO, M.; SCHULDENREIN, J. Special issue of Geoarchaeology: Urban geoarchaeology in the Mediterranean Basin. Geoarchaeology, 33, 3 12. doi: 10.1002/gea.21674, 2018.

BIRCK, J.; BATTARBEE, R.; MACAY, A.; OLDFIEL, F. Global Change in the Holocene. Holder Arnold, 2005, 480 p.

BONNIN, J. L'eau dans l'Antiquité. Eyrolles, 1985, 488 p.

BORSOS, E.; MAKRA, L.; BECZI, R.; VITANYI, B.; SZENTPÉTERI, M. Anthropogenic air pollution in the ancient times. Acta Climatologica et Chrorologica, 36-37, 5-15, 2003.

BOULIER, J.; DUBOS-PAILLARD, E.; PAVARD, A.; SANSEVERINO-GODFRIN, V. La difficile mise en application locale de la politique de prévention des risques. In: LUTOFF C.; DURAND, S. (eds). Mobilités face aux événements hydrométéorologiques 1. Définition des échelles de référence. Collection écologie, Iste éditions, Londres, p. 161-198, 2018. https://iste-editions.fr/products/mobilites-face-aux-evenements-hydrometeorologiquesextremes-1.

BRAVARD, J.-P.; MAGNY, M. Les fleuves ont une histoire. Paléo-environnements des rivières et des lacs français depuis $\mathbf{1 5 0 0 0}$ ans. Errance, Paris, 2002, 312 p. 
BRIANT, P. Irrigation et drainage dans l'Antiquité, Qanats et canalisations souterraines en Iran, en Égypte et en Grèce. Persika 2, Paris, 2001, 190 p.

BURKE, A. Walled Up to Heaven: The Evolution of Middle Bronze Age Fortification Strategies in the Levant. Brill, Leyde, 2008, p. 172.

BUTTERLIN, P. D'Uruk à Mari. Recherches récentes sur la première révolution urbaine en Mésopotamie. Histoire urbaine, 29, 133-159, 2010.

BUTZER, K. W. "Geoarchaeology, climate change, sustainability: A Mediterranean perspective”. In: BROWN, A. G.; BASELL, L. S.; BUTZER, K. W. (eds), Geoarchaeology, Climate Change, and Sustainability. Geological Society of America (Special Paper 476), Boulder, Colorado, p. 1-14, 2011.

CATTANI, M. "Margiana at the end of Bronze Age and beginning of Iron Age". In: KOSAREV, M. F.; KOZHIN, P. M.; DUBOVA, N. A. (eds). Uistokov civilizacii. Sbornik statej k 75-letiju Viktora Ivanovicha Sarianidi, Moscou, p. 303-315, 2005.

CREMASCHI, M. "Palaeohydrography and Middle Holocene Desertification in the Northern Fringe of the Murghab Delta". In: GUBAEV, A.; KOSHELENKO, G. A.; TOSI, M. (eds), The Archaeological Map of the Murghab Delta. Preliminary Reports 1990-95, Instituto Italiano per l'Africa e l'Oriente. Centro Scavi e Ricerche Archeologiche, Rome, p. 15-25, 1998.

DEGREMONT, C. Istanbul: le port byzantin de Yenikapi. Archeologia, 469, 16-25, 2009.

DIXIT, Y.; HODELL, D. A.; PETRIE, C. A. Abrupt weakening of the summer monsoon in northwest India 4100 yr ago. Geology, 42, 339-342, 2014.

DUTT, S.; GUPTA, A. K.; CLEMENS, S. C.; CHENG, H.; SINGH, R. K.; KATHAYAT, G.; EDWARDS, R. L. Abrupt changes in Indian summer monsoon strength during 33,800 to 5500 years BP. Geophys. Res. Lett., 42 (13), 5526-5532, 2015.

DUTT, S.; GUPTA, A. K.; SINGH, M.; SONU, J.; SARAVANAN, P.; BALACHANDIRAN, P.; AMAR, S. Climate variability and evolution of the Indus civilization. Quaternary International, 507, 25, 15-23, 2019.

EICKHOFF, T. Kār-Tukulti-Ninurta, Eine mittelassyrische Kult- und Rezidenzstadt, ADOG 21, Berlin, 1985.

FOUACHE, E. 10000 ans d'évolution des paysages en Adriatique et en Méditerranée Orientale. Travaux de la Maison de l'Orient Méditerranéen, Volume 45, Lyon, 2006, 225 p.

FOUACHE, E. "L'approche Géoarchéologique". In: ALARASHI, H.; CHAMBRADE, M.L.; GONDET, S.; JOUVENEL, A.; SAUVAGE, C.; TRONCHERE, H. (eds), Regards croisés sur l'étude archéologique des paysages anciens. Nouvelles recherches dans le Bassin méditerranéen, en Asie Centrale et au Proche et au Moyen-Orient, Maison de l'Orient et de la Méditerranée, Lyon, p. 17-30, 2010. 
FOUACHE, E.; LEZINE, A.-M.; ADLE, S.; BUCHSENSCHUTZ, O. "Le passé des villes pour comprendre leur futur". In: Varet J. (ed), Villes et géologie urbaine, Géosciences, 10, p. 54-61, 2009.

FOUACHE, E.; COSANDEY, C.; FRANCFORT, H.-P.; BENDEZU-SARMIENTO, J.; VAHDATI, A. A.; LHUILLIER, J. The Horst of Sabzevar and regional water resources from the Bronze Age to the present day (Northeastern Iran). Geodinamica Acta, 23/5-6, 287-294, 2010 .

FRANCFORT, H.-P. "La civilisation de l'Oxus et les Indo-Iraniens et Indo-Aryens". In: FUSSMAN, G.; KELLENS, J.; FRANCFORT, H.-P.; TREMBLAY, X. (eds), Aryas, Aryens et Iraniens en Asie Centrale, Collège de France, Paris, p. 253-328, 2005.

FRANCFORT, H.-P L'âge du bronze en Asie centrale. La civilisation de l'Oxus. Anthropology of the Middle East, 4 (1), 91-111, 2009.

FRANCFORT, H.-P.; TREMBLAY, X. Marhai et la civilisation de l'Oxus. Iranica Antiqua, 45, 51-224, 2010.

HAYS, J. N. Epidemics and pandemics: their impacts on human history. ABC-CLIO, 2005, $513 \mathrm{p}$.

HORNBLOWER, S.; SPAWFORTH, A.; EIDINOW, E. The Oxford Companion to Classical Civilization. Oxford University Press, 2014, 867 p.

ISSAR, A. S.; ZOHAR, M. Climate Change - Environment and History of the Near East, Springer-Verlag, Berlin, 2007, 290 p.

IVORY, S. I.; LÉZINE, A.-M. Climate and environmental change at the end of the Holocene Humid Period: a pollen record off Pakistan. CR Geoscience, 341, 8-9, 760-769, 2009.

LIRITZIS, I.; WESTRA, A.; MIAO, C. Disaster Geoarchaeology and Natural Cataclysms in World Cultural Evolution: An Overview. Journal of Coastal Research, 35 (6), 1307-1330, 2019. doi: https://doi.org/10.2112/JCOASTRES-D-19-00035.1.

KENNETT, D. J.; BEACH, T. P. Archeological and environmental lessons for the Anthropocene from the Classic Maya collapse. Anthropocene, 4, 88-100, 2013. dx.doi: 10.1016/j.ancene.2013.12.002

KENNETT, D. J.; BREITENBACH, S. F. M.; AQUINO, V. V.; ASMERSOM, Y.; AWE, J.; BALDINI, J. U. L.; BARTLEIN, P.; CULLETON, B. J.; EBERT, C.; JAZWA, C.; MACRI, M. J.; MARWAN, N.; POLYAK, V.; PRUFER, K. M.; RIDLEY, H. E.; SODEMANN, H.; WINTERHALDER, B.; HAUG, G. H. Development and disintegration of Maya political systems in response to climate change. Science, 338, 788-791, 2012.

KNAPP, B.; MANNING, S. W. Crisis in Context: The End of the Late Bronze Age in the Eastern Mediterranean. American Journal of Archaeology, 120, 1, 99-149, 2016. doi: 10.3764/aja.120.1.0099. 
KRAFT, J. C.; BRÜCKNER, H.; KAYAN, I.; ENGELMANN, H. The geographies of Ancient Ephesus and the Artemision in Anatolia. Geoarchaeology, 22, 1, 121-149, 2007.

KUZUÇUOGLU, C. ; MARRO, C. Sociétés humaines et changements climatiques à la fin du troisième millénaire: une crise a-t-elle eu lieu en Haute Mésopotamie? Institut français d'études anatoliennes, Istanbul, 2007, 590 p.

LEZINE, A. -M.; TIERCELIN, J. -J.; ROBERT, C.; SALIEGE, J. -F.; CLEUZIOU, S.; INIZAN, M. -L. ; BRAEMER, F. Centennial to millennial-scale variability of the Indian monsoon during the early Holocene from sediment, pollen, and isotope record from the desert of Yemen. Palaeogeography, Palaeoclimatology, Palaeoecology, 243, 235-249, 2007.

LIANG, W.; GU, X.; LI, X.; ZHANG, K.; WU, K.; PANG, M.; DONG, J.; MERRILL, H. R.; HU, T.; LIU, K.; SHAO, Z.; YAN, H. Mapping the epidemic changes and risks of hemorrhagic fever with renal syndrome in Shaanxi Province, China, 2005-2016. Sci Rep 8, 749, 2018. https://doi.org/10.1038

LIRITZIS, I.; WESTRA, A.; MIAO, C. Disaster geoarchaeology and natural cataclysms in world cultural evolution: An overview. Journal of Coastal Research, 35, 6, 1307-1330, 2019. DOI: 10.2112/JCOASTRES-D-19-00035.1

LIU, J.; WANG, Y.; WANG, Y.; GUANF, Y.; DONG, J.; LI, T. A multi-proxy record of environmental changes during the Holocene from the Haolaihure Paleolake sediments, Inner Mongolia. Quaternary International, 479, 148-159, 2018.

LUNEAU, E. L'âge du Bronze final en Asie centrale méridionale (1750-1500/1450 avant n.è.) : la fin de la civilisation de l'Oxus. Doctorat en Archéologie et Préhistoire, Université Panthéon-Sorbonne - Paris 1, 2010, 612 p.

LUNEAU, E. "Climate Change and the Rise and Fall of the Oxus Civilization in Southern Central Asia". In: YANG, L. E.; BORK, H. -R.; FANG, X.; MISCHKE, S. (eds), Socioenvironmental dynamics along the historical Silk Road. p. 275-299, 2019.

MARGUERON, J. -C. "Mari et le Khabur: enjeux, possibilités et difficultés d'une approche archéologique", In: ROUAULT, O.; WÄFLER, M. La Djéziré et l'Euphrate syriens de la protohistoire à la fin du second millénaire av. J.-C. Tendances dans l'interprétation historique des données nouvelles. Brepols, Turnhout, p. 99-110, 2000.

MARGUERON, J. -C. Mari: métropole de l'Euphrate au $\mathrm{III}^{\mathrm{e}}$ et au début du $\mathrm{II}^{\mathrm{e}}$ millénaire av. J.-C., ERC, Paris, 2004, 575 p.

MAYEWSKI, P.; ROHLING, E.; STAGER, J.; KARLEN, W.; MAASCH, K.; MEEKER, L.; MEYERSON, E.; GASSE, F.; VAN KREVELD, S.; HOLMGREN, K.; LEE-THORP, J.; ROSQVIST, G.; RACK, F.; STAUBWASSER, M.; SCHNEIDER, R.; STEIG, E. Holocene climate variability. Quaternary Research, 62, 243-255, 2004.

MODELSKI, G. World Cities: -3000 to 2000. FAROS 2000, Washington DC, 2003, 245 p. 
MORHANGE, C.; MARRINER, N.; SABATIER, F.; VELLA, C. Risques littoraux en Méditerranée. Méditerranée, 108, 2007, 149 p.

MORHANGE, C.; MARRINER, N.; CARAYON, N. "Chapter 21. The geoarchaeology of ancient Mediterranean harbours". In: CARCAUD, N.; ARNAUD-FASSETTA, G. (eds). La géoarchéologie française au xxi ${ }^{\mathrm{e}}$ siècle, p. 281-290, 2015.

NICOLLE, C. L'époque des premiers bourgs fortifiés: Pertinence de l'existence d'un processus d'urbanisation dans le Levant sud au troisième millénaire. Presses de l'Ifpo, Beyrouth, 2013, 135 p.

PEDERSEN, O. "Waters at Babylon". In: TVEDT, T.; OESTIGAARD, T. (eds). Water and urbanization, I.B. Tauris, London, p. 107-129, 2014.

T'HART, M.; BLOCKMANS, W. P. "Urban systems and urbanization in world history". In: ANTUNES, C., FATAH-BLACK, K. (eds.), Explorations in History and Globalization. Routledge, London, p. 113-137, 2016.

VEYRET, Y. Du risque à la gestion des villes : la ville durable. In: VARET, J. (ed). Villes et géologie urbaine. Géosciences, 10, p. 94-101, 2009.

VOISIN, B. Évocation historique du «Bassin de Saône, cour de Ville». Agence d'urbanisme pour le développement de l'agglomération lyonnaise, 2010, 96 p.

WALDRON, T. Palaeopathology. Cambridge University Press, 2009, 279 p.

WEISS, H.; COURTY, M. A.; WETTERSTROM, F.; GUICHARD, F.; SENIOR, L.; MEADOW, R.; CURNOW, A. The Genesis and Collapse of the Third Millennium North Mesopotamia Civilization, Science, 261, 995-1004, 1993.

ZHANG, Z. M.; LIOU, J. G.; COLEMAN, R. G. An outline of the plate tectonics of China. Geological Society of America Bulletin, 95, 295-312, 1984.

ZHANG, G. L.; YANG, F. G.; ZHAO, Y. G.; ZHAO, W. J.; YANG, J. L.; GONG, Z. T. Historical change of heavy metals in urban soils of Nanjing, China during the past 20 centuries. Environ Int., 31(6), 913-919, 2005. doi:10.1016/j.envint.2005.05.035. 